\title{
Indole-3-acetic acid (IAA) synthesis in the biocontrol strain CHAO of Pseudomonas fluorescens: role of tryptophan side chain oxidase
}

\author{
Thomas Oberhänsli, ${ }^{1}$ Geneviève Défago ${ }^{1 *}$ and Dieter HaAs $^{2}$ \\ Departments of Plant Sciences/Phytomedicine ${ }^{1}$ and Microbiology ${ }^{2}$, Swiss Federal Institute of Technology, \\ CH-8092 Zurich, Switzerland
}

(Received 10 May 1991; revised 11 July 1991; accepted 15 July 1991)

\begin{abstract}
Pseudomonas fuorescens strain CHA0 is an effective biocontrol agent against soil-borne fungal plant pathogens. In this study, indole-3-acetic acid (IAA) biosynthesis in strain CHAO was investigated. Two key enzyme activities were found to be involved: tryptophan side chain oxidase (TSO) and tryptophan transaminase. TSO was induced in the stationary growth phase. By fractionation of a cell extract of strain CHAO on DEAE-Sepharose, two distinct peaks of constitutive tryptophan transaminase activity were detected. A pathway leading from tryptophan to IAA via indole-3-acetamide, which occurs in Pseudomonas syringae subsp. savastanoi, was not present in strain CHAO. IAA synthesis accounted for $\leqslant 1.5 \%$ of exogenous tryptophan consumed by resting cells of strain CHA0, indicating that the bulk of tryptophan was catabolized via yet another pathway involving anthranilic acid as an intermediate. Strain CHA750, a mutant lacking TSO activity, was obtained after Tn5 mutagenesis of strain CHA0. In liquid cultures (pH 6.8) supplemented with 10 mM-L-tryptophan, growing cells of strains CHAO and CHA750 synthesized the same amount of IAA, presumably using the tryptophan transaminase pathway. In contrast, resting cells of strain CHA750 produced five times less IAA in a buffer (pH 6.0) containing 1 mM-L-tryptophan than did resting cells of the wild-type, illustrating the major contribution of TSO to IAA synthesis under these conditions. In artificial soils at $\mathrm{pH} \sim 7$ or $\mathrm{pH} \sim 6$, both strains had similar abilities to suppress take-all disease of wheat or black root rot of tobacco. This suggests that TSO-dependent IAA synthesis is not essential for disease suppression.
\end{abstract}

\section{Introduction}

Pseudomonas fluorescens strain CHA0 suppresses a variety of root diseases caused by soil-borne fungal pathogens (Stutz et al., 1986; Défago et al., 1990) and produces several secondary metabolites, notably $\mathrm{HCN}$, 2,4-diacetylphloroglucinol, pyoluteorin and indole3-acetic acid (IAA) (Défago et al., 1990; Défago \& Haas, 1990; Haas et al., 1991). HCN has been shown to be an important factor in the suppression of black root rot of tobacco, a disease caused by Thielaviopsis basicola (Voisard et al., 1989), and 2,4-diacetylphloroglucinol contributes significantly to the suppression of both black root rot of tobacco and take-all of wheat, a disease caused by Gaeumannomyces graminis var. tritici (Keel et al., 1990, 1991). Many plant-beneficial Pseudomonas strains, isolated from the rhizosphere, produce IAA (Loper \&

Abbreviations: IAA, indole-3-acetic acid; KB, King's medium B; MES, 2-morpholinoethanesulphonic acid; NA, nutrient agar; NYB, nutrient yeast broth; OS medium, Ornston \& Stanier medium; TSO, tryptophan side chain oxidase.
Schroth, 1986; Müller et al. 1989). In bacteria, several pathways have been described leading from L-tryptophan (Trp) to IAA (Fig. 1). In a strain of $P$. fluorescens (ATCC 29574), one of these pathways is initiated by tryptophan side chain oxidase (TSO) (Narumiya et al., 1979). An IAA biosynthetic pathway involving indolepyruvic acid as an intermediate occurs in Agrobacterium tumefaciens (Kaper \& Veldstra, 1958) and in a bacterium isolated from the rhizosphere of Festuca octoflora (Frankenberger \& Poth, 1988). In Pseudomonas syringae subsp. savastanoi, the olive and oleander knot pathogen, the biosynthesis of IAA via indolepyruvic acid is of minor significance compared to the formation of IAA via indoleacetamide (Kuo \& Kosuge, 1970).

Here we report two pathways of Pseudomonas fluorescens strain $\mathrm{CHA} 0$ contributing to IAA production and we tested the influence of different incubation conditions on the amount of IAA produced. By isolating a Tn5 insertion mutant lacking TSO, we could assess the contribution of this enzyme to IAA formation and to disease suppression. 


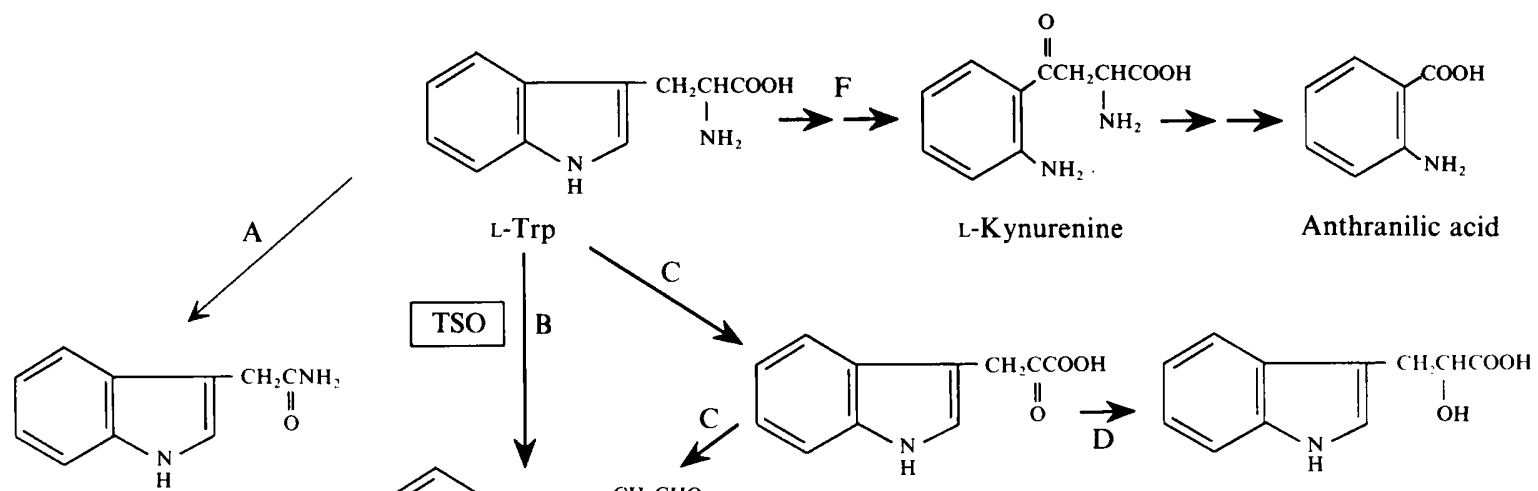

Indole-3-acetamide<smiles>CC=CCc1c[nH]c2ccccc12</smiles>

Indole-3-pyruvic acid

Indole-3-lactic acid<smiles>CCc1c[nH]c2ccccc12</smiles>

Indole-3-acetaldehyde<smiles>C1CCCC1</smiles><smiles>O=Cc1c[nH]c2ccccc12</smiles>

Indole-3-aldehyde

Indole-3-ethanol<smiles>O=C(O)Cc1c[nH]c2ccccc12</smiles>

IAA

Fig. 1. Bacterial pathways leading from Trp to IAA: A, indoleacetamide pathway of $P$. syringae subsp. savastanoi, catalysed by Trp-2-mono-oxygenase and indoleacetamide hydrolase (Comai \& Kosuge, 1980); B, TSO and indoleacetaldehyde dehydrogenasecatalysed formation of IAA (Narumiya et al., 1979) [in addition to indoleacetaldehyde, TSO also produces indoleglycolaldehyde and indoleglyoxal (not shown; Narumiya et al., 1979)]; C, indolepyruvic acid pathway initiated by L-Trp transaminase (Frankenberger \& Poth, 1988); D, enzymic formation of indolelactate (Kaper \& Veldstra, 1958); E, indole-ethanol dehydrogenase (Narumiya et al., 1979); F, ring cleavage pathway initiated by Trp-2,3-dioxygenase leading to kynurenine and anthranilic acid (Narumiya et al., 1979). Pathways of strain CHA0 are indicated with bold arrows (reactions B, C, D, E, F). Indolepyruvic acid is unstable and gives rise to a nonenzymic formation of IAA and indolealdehyde (Kaper \& Veldstra, 1958).

\section{Methods}

Micro-organisms and growth conditions. The strains used were Pseudomonas fluorescens strain CHA0 (Stutz et al., 1986) and its Trp auxotrophic derivative CHA104 (trp-104::Tn5; obtained from C. Voisard, Department of Microbiology, Swiss Federal Institute of Technology, Zürich, Switzerland), Pseudomonas savastanoi strain 229 isolated from Nerium oleander (Wädenswil, Switzerland), Thielaviopsis basicola (Berk. and Br.) Ferraris ETH strain D127, and Gaeumannomyces graminis (Sacc.) Olivier and Von Arx var. tritici Walker ETH strain 1000. The Pseudomonas strains were grown on King's medium B (KB) agar (King et al., 1954), nutrient agar (NA) (Stanisich \& Holloway, 1972), and in nutrient yeast broth (NYB); NYB contained $\left(1^{-1}\right) 25 \mathrm{~g}$ nutrient broth and $5 \mathrm{~g}$ yeast extract (both Difco). NA and NYB were supplemented with kanamycin sulphate $\left(25 \mu \mathrm{g} \mathrm{ml}^{-1}\right)$ for the selection of Tn 5 derivatives of strain CHA0. For enzyme determinations and IAA measurements the bacteria were grown on a rotary shaker (120 r.p.m.) at $27^{\circ} \mathrm{C}$ in $500 \mathrm{ml}$ Erlenmeyer flasks containing $200 \mathrm{ml}$ minimal medium OS with $5 \mathrm{~g}$ glucose $\mathrm{l}^{-1}$ as the carbon source (Ornston \& Stanier, 1966). In some cases L-Trp (sterilized by filtration) was added to a final concentration of $10 \mathrm{mM}$. T. basicola and G. graminis var. tritici were grown on malt agar and millet, respectively, at $24^{\circ} \mathrm{C}$ (Keel et al., 1989, 1991).
Preparation of cell extracts. Cells grown in minimal medium OS with or without $10 \mathrm{mM}$-L-Trp were harvested by centrifugation at $4{ }^{\circ} \mathrm{C}$ after $16 \mathrm{~h}$ (exponential phase) or $36 \mathrm{~h}$ (stationary phase), washed twice with ice-cold potassium phosphate buffer (100 mM, pH 7.5) and resuspended in the same buffer to obtain a $15 \%(\mathrm{w} / \mathrm{v})$ suspension. Cells were disrupted with an ultrasonic homogenizer (Braun Labsonic 2000) by 5 pulses of $10 \mathrm{~s}$, and cell debris was sedimented at $50000 \mathrm{~g}$ at $4{ }^{\circ} \mathrm{C}$ for $20 \mathrm{~min}$. The crude cell extract was used directly for enzyme assays. For chromatography on DEAE-Sepharose and for transaminase assays, the cell extract was desalted on a Sephadex G-25 column (PD-10, Pharmacia) which was equilibrated with a $25 \mathrm{~mm}$-potassium phosphate buffer (pH 7.5).

Enzyme assays. (a) Trp transaminase. The reaction mixture consisted of L-Trp and 2-oxoglutarate ( $5 \mathrm{mM}$ each), $50 \mu \mathrm{M}$-pyridoxal phosphate, $0.5 \mathrm{~mm}$-sodium arsenate and $0.5 \mathrm{~mm}$-EDTA in $50 \mathrm{~mm}$-borate $/ \mathrm{HCl}$ buffer ( $\mathrm{pH} \mathrm{8.5).} \mathrm{The} \mathrm{formation} \mathrm{of} \mathrm{indolepyruvate} \mathrm{as} \mathrm{a} \mathrm{stable} \mathrm{enol}$ tautomer-borate complex was measured as the increase in $A_{327}$ at $25^{\circ} \mathrm{C}$ (Frankenberger \& Poth, 1988). The concentration of indolepyruvate was calculated from a standard curve of indolepyruvic acid (Fluka) in borate buffer containing EDTA and sodium arsenate as above, and an $\varepsilon_{\mathrm{mM}}$ of $17.85 \mathrm{~cm}^{-1}$ was obtained. 
(b) Phenylalanine transaminase was measured in the same reaction mixture as above but with $5 \mathrm{mM}$-L-phenylalanine (L-Phe) instead of L-Trp. The formation of phenylpyruvate was determined by measuring $A_{300}$, using an $\varepsilon_{\mathrm{mm}}$ of $9.15 \mathrm{~cm}^{-1}$ (Fujioka et al., 1970).

(c) Trp-2-mono-oxygenase and indoleacetamide hydrolase were measured according to Comai \& Kosuge (1980). The reaction products indoleacetamide and IAA were quantified by HPLC (see below). Pseudomonas savastanoi strain 227 served as a reference.

(d) TSO. The formation of $N$-acetyl- $\alpha, \beta$-didehydrotryptophanamide was measured as the increase in $A_{333}$ at $25^{\circ} \mathrm{C}$ with $1 \mathrm{mM}-N$-acetylL-tryptophanamide (Sigma) as substrate in $50 \mathrm{~mm}$-potassium phosphate buffer (pH 6.0) (Narumiya et al. 1979).

(e) Indoleacetaldehyde dehydrogenase was measured according to Fujioka et al. (1970), as the $A_{340}$ increase due to NADH formation.

One unit of the enzyme activities described above is defined as the formation of $1 \mu \mathrm{mol}$ product $\mathrm{min}^{-1}$. The enzyme activities determined are average values of at least two independent experiments.

Fractionation on DEAE-Sepharose. Desalted cell extract $(5 \mathrm{ml})$ was applied to a DEAE-Sepharose column (CL-6B, Pharmacia; $1.6 \times 11 \mathrm{~cm})$ equilibrated with $25 \mathrm{~mm}$-potassium phosphate buffer (pH 7.5). Elution was performed over a period of $11 \mathrm{~h}$ with a linear gradient formed by mixing $25 \mathrm{mM}$-potassium phosphate (pH 7.5) with $100 \mathrm{~mm}$-potassium phosphate ( $\mathrm{pH} 7.5$ ) containing $0.5 \mathrm{M}-\mathrm{NaCl}$. The flow rate was $13.5 \mathrm{ml} \mathrm{h}^{-1}$ and fractions of $2.7 \mathrm{ml}$ were collected. Trp transaminase was eluted in fractions $27-32$ and $49-53$.

Protein determination. Protein concentration was determined by the Bio-Rad Protein Microassay according to Bradford (1976) with bovine serum albumin as standard.

IAA determination. Bacterial IAA production was measured either in liquid OS cultures with or without $10 \mathrm{mM}-\mathrm{L}-\operatorname{Trp}$ at 24,48 and $72 \mathrm{~h}$, or in suspensions of resting cells. Resting cells were harvested from NYB cultures at $36 \mathrm{~h}$, in the stationary phase of growth, by centrifugation at $4000 \mathrm{~g}$ for $20 \mathrm{~min}$. The cells were washed twice with $0.01 \mathrm{M}$-potassium phosphate buffer ( $\mathrm{pH} 6.5)$ and resuspended in 0.1 M-potassium phosphate buffer ( $\mathrm{pH} 6$ or 7 ) or in $0 \cdot 1 \mathrm{M}-2$-morpholinoethanesulphonic acid (MES)/potassium phosphate buffer ( $\mathrm{pH} 5 \cdot 5$ ), respectively, to a concentration of approximately $1.5 \times 10^{9}$ c.f.u. $\mathrm{ml}^{-1}$. L-Trp was added to a final concentration of $1 \mathrm{mM}$. IAA production was measured in the supernatant during incubation on a gyratory shaker $(120$ r.p.m.) at room temperature over a period of $6 \mathrm{~h}$.

For IAA extraction, $10 \mathrm{ml}$ bacterial suspension was centrifuged at $4000 \mathrm{~g}$ for $15 \mathrm{~min}$ and the supernatant was acidified to $\mathrm{pH} 2 \cdot 5-3.0$ with $\mathrm{HCl}$. Apolar compounds were extracted wtih a Waters Sep-Pack C-18 cartridge (Sandberg et al., 1987), eluted with methanol, reduced to dryness and redissolved in $0.5 \mathrm{ml} 65 \%(\mathrm{v} / \mathrm{v})$ methanol for HPLC, or in $0.2 \mathrm{ml}$ ethyl acetate for TLC. The HPLC system (Hewlett Packard $1090 \mathrm{~L})$ used a reversed-phase Nucleosil $120-5 \mathrm{C}_{8}$ column $(250 \times 4 \mathrm{~mm}$; Macherey and Nagel, Oensingen, Switzerland), which was thermostatically controlled at $45^{\circ} \mathrm{C}$. Injection volume was 1-10 $\mu$ and elution was performed with increasing concentrations of methanol in $0.025 \%$ ethanolamine/water acidified with phosphoric acid to $\mathrm{pH} 2 \cdot 7$. A twostep linear gradient of $20-42 \%$ methanol $(0-8 \mathrm{~min})$ and $42-46 \%$ methanol $(8-15 \mathrm{~min})$ was used. The flow rate was $1 \mathrm{ml} \mathrm{min}^{-1}$. Compounds were detected in series by a UV diode array detector at 280, 300 and $327 \mathrm{~nm}$, and a fluorescence detector (Shimadzu RF-510LC; excitation: $280 \mathrm{~nm}$, emission: $360 \mathrm{~nm}$ ). Integration of peak areas was performed with the 'ChemStation'-software (Hewlett Packard).

For TLC, 20-100 $\mu \mathrm{l}$ of the extracts was applied on silica plates and chromatographed with chloroform/ethyl acetate/formic acid $(5: 4: 1$, by vol.). The separated compounds were visualized by colour development with Ehrlich reagent (Hartmann et al., 1983).
Transposon insertion mutagenesis. This was performed as described by Voisard et al. (1989) with strain CHA0 as the recipient and Escherichia coli strain W3110(pLG221) as the donor. TSO activity of the mutants obtained was detected by overlaying 4-d-old colonies on KB plates with agar $(1.2 \%, \mathrm{w} / \mathrm{v})$ containing $10 \mathrm{mM}-\mathrm{L}-\mathrm{Trp}$ and $0.5 \% \mathrm{SDS}$ in $0.5 \mathrm{M}-$ glycine/ $\mathrm{HCl}$ buffer at $\mathrm{pH} 3$ (Takai \& Hayaishi, 1987). Colonies of TSOpositive strains turned dark upon incubation at room temperature overnight, whereas TSO-negative colonies remained white.

The TSO-negative isolates were screened for known products of strain CHA0 (HCN, 2,4-diacetylphloroglucinol, pyoluteorin and pyoverdine) according to methods described earlier (Keel et al., 1989, 1990; Voisard et al., 1989).

The gnotobiotic system. This has been described in detail elsewhere for tobacco (Keel et al., 1989). Briefly, an artificial soil was made up from pure vermiculite clay (expanded with $30 \% \mathrm{H}_{2} \mathrm{O}_{2}$ ), quartz sand and quartz powder at $(10: 70: 20$, by wt). After moistening with $10 \%$ (w/w) $\mathrm{H}_{2} \mathrm{O}$, the soil was distributed into flasks, which were plugged with cotton-wool and autoclaved. The soil volume was $75 \mathrm{~cm}^{3}$ per flask for tobacco, and $400 \mathrm{~cm}^{3}$ per 1 litre Erlenmeyer flask for wheat. $P$. fluorescens $\left(10^{7}\right.$ c.f.u. per $\mathrm{cm}^{3}$ soil $), T$. basicola $\left(5 \times 10^{3}\right.$ endoconidia per $\mathrm{cm}^{3}$ soil) for tobacco or $G$. graminis var. tritici grown on millet $\left(1.25 \mathrm{mg}\right.$ per $\mathrm{cm}^{3}$ soil) for wheat were added. After incubation for 1 week, sterile-grown tobacco plants (Nicotiana glutinosa $\mathbf{L}$.) with four leaves or 2-d-old sterile-grown wheat seedlings (Triticum aestivum cv. Arina) were transplanted into the soil and supplemented with modified Knop nutrient solution (Keel et al., 1989). Plants were grown in growth chambers at $18^{\circ} \mathrm{C}$ (light, $12 \mathrm{~h}$ ) and $13{ }^{\circ} \mathrm{C}$ (dark, $12 \mathrm{~h}$ ) for wheat, and at $22^{\circ} \mathrm{C}$ (light, $16 \mathrm{~h}$ ) and $15^{\circ} \mathrm{C}$ (dark, $8 \mathrm{~h}$ ) for tobacco. After 3 weeks plants were weighed and assessed for disease severity (Stutz et al., 1986; Keel et al., 1989; Weller \& Cook, 1983). The means of three experiments consisting of eight replicates per experiment and one tobacco plant per replicate, or three replicates per experiment and five wheat plants per replicate, respectively, were analysed statistically using the Student's $t$-test $(P=0 \cdot 05)$. Each mean was compared to each other in real numbers. To lower the $\mathrm{pH}$ of the rhizosphere, $\mathrm{Ca}\left(\mathrm{NO}_{3}\right)_{2}$ of the Knop nutrient solution was substituted by $1.7 \mathrm{mM}-\mathrm{CaCl}_{2}$ and $4.2 \mathrm{~mm}-\left(\mathrm{NH}_{4}\right)_{2} \mathrm{SO}_{4}$ (Smiley \& Cook, 1973). To obtain a lower $\mathrm{pH}$ of the soil, $80 \%$ of the vermiculite mixed in the soil was treated with $\mathrm{HCl}$. To achieve this, $100 \mathrm{~g}$ expanded $\left(\mathrm{H}_{2} \mathrm{O}_{2}\right)$ and ground $(120 \mu \mathrm{m})$ vermiculite (Keel et al., 1989) was suspended in $450 \mathrm{ml} 0.44 \mathrm{M}-\mathrm{HCl}$, stirred for $15 \mathrm{~min}$ and washed three times with distilled water. The $\mathrm{pH}$ of the artificial soil was measured according to the method of Smiley \& Cook (1973): $10 \mathrm{~g}$ of soil was suspended in $25 \mathrm{ml} 10 \mathrm{~mm}-\mathrm{CaCl}_{2}$, shaken for $1 \mathrm{~h}$ at 200 r.p.m. at room temperature and centrifuged at $4000 \mathrm{~g}$ for $5 \mathrm{~min}$. For measuring the rhizosphere $\mathrm{pH}$, roots were shaken in $10 \mathrm{~mm}$ $\mathrm{CaCl}_{2}$ to suspend the adhering soil. The $\mathrm{pH}$ was measured $5 \mathrm{~min}$ after introducing the electrode into the clear supernatant.

Reagents. These were of the highest purity grade available and were obtained from Fluka (Buchs, Switzerland) except $N$-acetylL-tryptophanamide, indole-3-acetaldehyde sodium bisulphite and indole-3-acetamide, which were obtained from Sigma.

\section{Results and Discussion}

\section{IAA pathways of strain $\mathrm{CHAO}$}

The enzymes catalysing the initial steps of three bacterial IAA pathways (Fig. 1) were assayed in strain CHA0. Trp transaminase and TSO activities were detected (Table 1) whereas no Trp mono-oxygenase and indoleacetamide 


\section{Table 1. Enzyme activities of cell extracts of strain $\mathrm{CHAO}$}

All cultures were grown in OS minimal medium with or without $10 \mathrm{~mm}$-L-Trp. Cell extracts were prepared as described in Methods. Mean values of two separate experiments did not differ by more than about $\pm 12 \%$ of the mean value.

\begin{tabular}{|c|c|c|}
\hline \multirow{2}{*}{$\begin{array}{l}\text { Culture } \\
\text { conditions }\end{array}$} & \multicolumn{2}{|c|}{ Specific activity $\left[\mathrm{mU}(\mathrm{mg} \text { protein })^{-1}\right]$} \\
\hline & TSO & Trp transaminase \\
\hline Exponential* - Trp & $<0.2$ & $6 \cdot 2$ \\
\hline Exponential ${ }^{*}+$ Trp & $<0 \cdot 2$ & 8.5 \\
\hline Stationaryt - Trp & 14.5 & 6.9 \\
\hline Stationary + + Trp & 3.8 & $9 \cdot 4$ \\
\hline
\end{tabular}

* Cells harvested in the exponential phase of growth after $16 \mathrm{~h}$. The cell density was approximately $10^{8}$ c.f.u. $\mathrm{ml}^{-1}$.

$\dagger$ Cells harvested in the stationary phase of growth after $36 \mathrm{~h}$. The cell density was approximately $1.5 \times 10^{9}$ c.f.u. $\mathrm{ml}^{-1}$.

hydrolase activities could be measured $[<0.01 \mathrm{mU}(\mathrm{mg}$ protein $\left.)^{-1}\right]$; in a $P$. syringae subsp. savastanoi strain, used as a positive control, the latter two enzymes were readily detectable [ $>8 \mathrm{mU}(\mathrm{mg} \text { protein })^{-1}$ ]. By fractionation of a cell extract of strain CHA0 on DEAE-Sepharose, two distinct peaks of Trp transaminase activity were found (data not shown). The specific activity in both peaks was constitutive, i.e. not dependent on the presence of L-Trp in the growth medium. The substrate specificity of the two transaminase fractions was not determined; however, both also had activity toward L-Phe. TSO activity appeared only in cell extracts of stationary-phase cultures and was repressed fourfold by the addition of $10 \mathrm{mM}-\mathrm{L}-\mathrm{Trp}$ to the culture medium (Table 1). Specific TSO activity was higher in cells of strain CHA 0 grown in NYB and harvested after $36 \mathrm{~h}$ [approximately $20 \mathrm{mU}$ (mg protein $)^{-1}$ ] than in cells grown in the defined OS medium (Table 1).

TSO is reported by Takai \& Hayaishi (1987) to catalyse a broad spectrum of reactions in vitro where the side-chain of Trp and other indole derivatives, or even Trp residues in polypeptides and proteins, are oxidized. Studies by Narumiya et al. (1979) showed that resting cells of $P$. fluorescens (ATCC 29574) incubated with Trp produce indole-3-acetaldehyde, indoleglycolaldehyde and indoleglycoi. Each of these indolealdehydes is further oxidized or reduced to the corresponding indole acid or alcohol, respectively, by the action of an aldehyde dehydrogenase or an alcohol dehydrogenase. However, in Fig. 1 only one product of TSO, indoleacetaldehyde, is shown because this compound is a precursor of IAA. Indoleacetaldehyde dehydrogenase, which produces IAA (Fig. 1), was constitutive in strain CHA0; cell extracts of both exponential and stationary OS cultures had a specific activity of approximately $2 \mathrm{mU}$ $(\mathrm{mg} \text { protein })^{-1}$.
Indolepyruvic acid, the intermediary product of the pathway initiated by Trp transaminase, is decomposed spontaneously to IAA and indolealdehyde, whereas indolelactic acid is formed enzymically (Kaper \& Veldstra, 1958). In OS medium, IAA formation by the spontaneous breakdown of indolepyruvic acid could be measured but did not account for the bulk of IAA measured in the culture supernatant of strain $\mathrm{CHA0}$ (data shown below). Therefore, an enzymic conversion of indolepyruvic acid to indoleacetaldehyde and IAA by strain CHA0 can be assumed.

\section{Tn5 insertion mutagenesis}

Since strain CHA0 has two different pathways for the synthesis of IAA, and two distinct fractions with Trp transaminase activity were. detected after chromatography on DEAE-Sepharose, it was not surprising that no Tn 5 insertion mutants were found which were totally IAA-negative (data not shown). For this reason we focused on mutants lacking TSO; among 2200 kanamycin-resistant colonies isolated after $\operatorname{Tn} 5$ mutagenesis, five were $\mathrm{TSO}^{-}$on malt and $\mathrm{KB}$ agar. Colonies of strain CHA0 and most of the putative Tn 5 insertion mutants, which were overlaid by the Trp-agar, turned tancoloured to dark brown overnight, whereas TSOdeficient colonies remained colourless. The $\mathrm{TSO}^{-}$phenotype of the five mutants was verified by the $\mathrm{N}$-acetylL-tryptophanamide enzyme assay with cell extracts. The five $\mathrm{TSO}^{-}$mutants were also screened for other extracellular products of strain CHA0. One of these mutants showed a pleiotropic deficiency in the production of 2,4-diacetylphloroglucinol, whereas four of them produced wild-type amounts of HCN, 2,4-diacetylphloroglucinol, pyoluteorin and pyoverdine and were assumed to be specifically defective in TSO formation. One representative of the latter type was named CHA750 and retained for further studies.

\section{Role of TSO in IAA production by cells of P. fluorescens strain $\mathrm{CHAO}$}

IAA and several other Trp derivatives were separated by HPLC and quantified according to their fluorescence. The retention times of indole compounds were $4.8 \mathrm{~min}$ for Trp, $8 \cdot 1 \mathrm{~min}$ for indoleacetamide, $10 \cdot 1 \mathrm{~min}$ for IAA, and $10.8 \mathrm{~min}$ for indoleacetaldehyde and indole-ethanol, which were not separated under these conditions (Fig. 2). Indolealdehyde and indolepyruvic acid were eluted at 11.7 and $13.3 \mathrm{~min}$, respectively, and detected by absorbance at 300 and $327 \mathrm{~nm}$, respectively, with a detection limit of $50 \mathrm{ng}$. The detection limit for compounds detected by fluorescence was between 1 and $5 \mathrm{ng}$, and $10 \mathrm{ng}$ for Trp. The determination of IAA by HPLC was verified by TLC: blue-coloured spots of the culture 


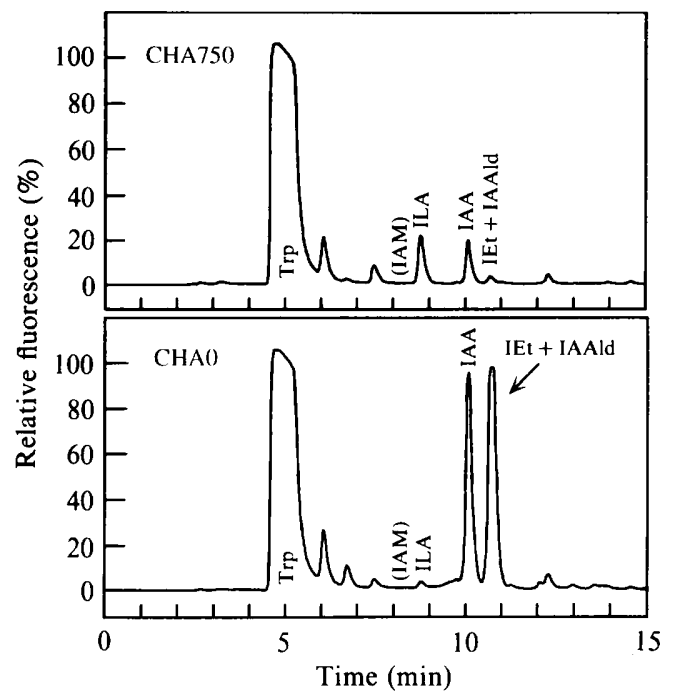

Fig. 2. HPLC separation of supernatants of resting cells of the TSOdeficient $\mathrm{Tn} 5$ insertion mutant $\mathrm{CHA750}$ and its parent strain $\mathrm{CHA0}$. The cells were grown in NYB for $36 \mathrm{~h}$ and suspended in $100 \mathrm{~mm}-$ MES/potassium phosphate buffer (pH 5.5) containing 1 mM-L-Trp. Incubation time was $6 \mathrm{~h}$. Synthetic indole compounds were used for calibration of the HPLC system and for tentative identification of fluorescent compounds produced and released by the cells. For conditions of separation, see Methods. Abbreviations: IAA, indole3-acetic acid; IAAld, indole-3-acetaldehyde; IAM, indole3-acetamide; IEt, indole-3-ethanol; ILA, indole-3-lactic acid; Trp, L-tryptophan.

supernatants corresponded to the $R_{F}$ value $(0.51-0.55)$ and to the colour formed by spots of synthetic IAA.

Resting cells were incubated in the presence of $1 \mathrm{~mm}$ L-Trp at pH 5.5 for $6 \mathrm{~h}$. The supernatant of strain CHA750 contained a reduced amount of IAA, as compared to the wild-type (Fig. 2). Moreover, the relative amounts of indolelactate excreted by strain CHA750 were elevated and those for indole-ethanol/ indoleacetaldehyde reduced, suggesting that the residual amount of IAA produced by the mutant was synthesized via the indolepyruvic acid pathway (Fig. 1). In contrast, for strain CHA0, the indolepyruvic acid pathway seemed to be of minor significance compared to the TSOcatalysed formation of indoleacetaldehyde and IAA under these conditions (Fig. 1). The effect of $\mathrm{pH}$ on IAA production was assessed. At $\mathrm{pH} 5 \cdot 5$, resting cells of strain CHA750 produced up to ten times less IAA than did cells of strain CHA0. At pH 6, there was a 5-fold difference and at neutral $\mathrm{pH}$ the production of the mutant was 1.5-fold lower (Table 2). This suggests that the TSO pathway, at $\mathrm{pH}$ values below 7 , accounts for most of the IAA produced by strain CHA0.

When strains CHA0 and CHA750 were grown in liquid cultures at $\mathrm{pH} 6.8$ with $10 \mathrm{~mm}-\mathrm{L}-\mathrm{Trp}$, no significant differences in IAA accumulation were measured. This can be explained by the repression of TSO when
Table 2. IAA production of resting cells in buffers containing $1 \mathrm{mM}-\mathrm{L}$-Trp

Cells were harvested in the stationary phase of growth $(36 \mathrm{~h})$ of an NYB culture. Cell density was approximately $1.5 \times 10^{9}$ cells $\mathrm{ml}^{-1}$. The release of IAA was measured in the supernatant at 2, 4 and $6 \mathrm{~h}$, and during this period IAA production was a linear function of incubation time. The mean values and standard error of two separate experiments with three repetitions per experiment are given.

\begin{tabular}{llcc}
\hline \hline \multirow{2}{*}{ Strain } & \multicolumn{3}{c}{ IAA production $\left[\mathrm{nM} \mathrm{h}^{-1}\right]$ at: } \\
\cline { 2 - 4 } CHA0 & $\mathrm{pH} \mathrm{7.0^{* }}$ & $\mathrm{pH} \mathrm{6.0^{* }}$ & $\mathrm{pH} \mathrm{5 \cdot 5 \dagger}$ \\
CHA750 & $167 \pm 11$ & $322 \pm 9$ & $494 \pm 18$ \\
\hline \hline & $117 \pm 6$ & $63 \pm 20$ & $46 \pm 6$ \\
& $* 100$ mM-potassium phosphate buffer. \\
& $\dagger 100$ mM-MES/potassium phosphate buffer.
\end{tabular}

$10 \mathrm{mM}-\mathrm{L}-\mathrm{Trp}$ is present in liquid cultures (Table 1) and with the $\mathrm{pH}$ value of the OS medium used (pH 6.8). Both strains accumulated approximately 2,7 and $20 \mu \mathrm{M}$-IAA after 24,48 and $72 \mathrm{~h}$ of growth, respectively. After $18 \mathrm{~h}$, cells entered the stationary growth phase. In these cultures both strains produced, in addition to IAA, readily detectable amounts of indolepyruvic acid (approximately $15 \mu \mathrm{M}$ after $24 \mathrm{~h}$ ), indolelactic acid (approximately $12 \mu \mathrm{M}$ after $72 \mathrm{~h}$ ), indoleacetaldehyde/ indole-ethanol (approximately $7 \mu \mathrm{M}$ after $72 \mathrm{~h}$, calculated with indole-ethanol as standard) and indolealdehyde (approximately $1 \mu \mathrm{M}$ after $72 \mathrm{~h}$ ). The accumulation of these intermediary products suggests a conversion of Trp to IAA initiated by Trp transaminase (Fig. 1). Indolepyruvic acid was only detected in supernatants of bacterial cultures after $24 \mathrm{~h}$. Incubation of $20 \mu \mathrm{M}$-indolepyruvic acid in sterile OS medium for $72 \mathrm{~h}$ under the same conditions as the bacterial cultures gave rise to an accumulation of approximately $2 \mu \mathrm{M}$-IAA and $1 \mu \mathrm{M}$ indolealdehyde but no indolelactate, which is in accordance with the data of Kaper \& Veldstra (1958).

Traces of IAA $(0 \cdot 1-0.5 \mu \mathrm{M})$ were determined in OS cultures of strains CHA0 and CHA750 supplemented with $0.5 \mathrm{~mm}$ - or without L-Trp after 48 and $72 \mathrm{~h}$. The amounts of IAA produced by strain $\mathrm{CHA} 0$ are smaller by several orders of magnitude than those synthesized by Azospirillum brasilense (Tien et al., 1979) or by $P$. syringae subsp. savastanoi (Surico et al., 1985) in liquid cultures containing $0.5 \mathrm{mM}-\mathrm{L}-\mathrm{Trp}$. Only $0.1-1.5 \%$ of the L-Trp metabolized was converted to IAA by resting cells of strain CHA0. This is probably due to the competition of Trp-catabolizing pathways other than those shown in Fig. 1, such as the conversion of L-Trp to L-kynurenine and anthranilic acid. This pathway is initiated by Trp-2,3-dioxygenase and has been described for other $P$. fluorescens strains (Ishimura, 1970; Narumiya et al., 
1979). There is circumstantial evidence that this pathway occurs in strain CHA0. Strain CHA0 was able to grow in OS medium with L-Trp as the sole C source, and in the supernatant of OS cultures, supplemented with $10 \mathrm{~mm}$ L-Trp, a compound co-eluting with authentic anthranilic acid was detected by HPLC at $327 \mathrm{~nm}$, with a retention time of $6.3 \mathrm{~min}$. The UV spectrum of this fraction was identical to that of synthetic anthranilic acid. The kynurenine pathway probably competes with the IAA biosynthetic pathways for Trp. When culture media containing glucose as a $\mathrm{C}$ source were supplemented with $10 \mathrm{~mm}-\mathrm{L}-\mathrm{Trp}$, only part of this amount of Trp was metabolized during cell growth and some Trp was still available for IAA synthesis.

Strain CHA104, which is auxotrophic for Trp, was able to grow on roots of tobacco and wheat plants to the same extent as did strain CHA0 (data not shown). This provides evidence that Trp was present in root exudates.

\section{Influence of the TSO mutation on disease suppression}

Protection of tobacco from black root rot and of wheat from take-all disease by strains $\mathrm{CHA0}$ and CHA750 was assessed in gnotobiotic systems containing artificial, vermiculite or acidified vermiculite soil. Fresh weight of plants grown without micro-organisms was taken as $100 \%$. Plants grown in the presence of the pathogen alone weighed $21 \%$ in the case of tobacco and $50 \%$ in the case of wheat. Tobacco plants protected by strains CHA 0 and CHA750 weighed 72 and $76 \%$, respectively, and wheat plants 88 and $90 \%$, respectively. Both strains also gave the same protection in terms of disease severity (data not shown). The rhizosphere $\mathrm{pH}$ was approximately 6.9-7.0 in the soil containing untreated vermiculite, and 5.9-6.1 in acidified vermiculite. We would like to point out that the $\mathrm{pH}$ was measured in the rhizosphere with some soil still adhering to the roots and it is likely that the $\mathrm{pH}$ at the root surface was somewhat lower (Smiley \& Cook, 1973). When P. fluorescens is in the stationary growth phase and at $\mathrm{pH}$ values of $\leqslant 6 \cdot 0$, the contribution of TSO to IAA production is important (Table 2). However, the fact that the $\mathrm{TSO}^{-}$mutant CHA750 gave normal disease suppression at $\mathrm{pH} \sim 7$ as well as $\mathrm{pH} \sim 6$ leads us to conclude that the TSO pathway does not have an important role in disease suppression.

This work was supported by the Schweizerischer Nationalfonds (project 31-25321.88).

\section{References}

BRADFORD, M. M. (1976). A rapid and sensitive method for the quantification of microgram quantities of protein utilizing the principle of protein-dye binding. Analytical Biochemistry 72, 248-254.
Comai, L. \& Kosuge, T. (1980). Involvement of plasmid deoxyribonucleic acid in indoleacetic acid synthesis in Pseudomonas savastanoi. Journal of Bacteriology 143, 950-957.

Défago, G., Berling, C. H., Burger, U., HaAs, D., KaHR, G., Keel, C., VoISARD, C., WIRTHNer, P. \& WÜTHRICH, B. (1990). Suppression of black root rot of tobacco and other root diseases by strains of Pseudomonas fluorescens: potential applications and mechanisms. In Biological Control of Soil-Borne Pathogens, pp. 93-108. Edited by D. Hornby, R. J. Cook, Y. Henis, W. H. Ko, A. D. Rovira, B. Schippers \& P. R. Scott. Wallingford: CAB International.

DéfaGo, G. \& HaAs, D. (1990). Pseudomonads as antagonists of soilborne plant pathogens: modes of action and genetic analysis. In Soil Biochemistry, vol. 6, pp. 249-291. Edited by J. M. Bollag \& G. Stotzky. New York \& Basel: Marcel Dekker.

Frankenberger, W. T. \& Poth, M. (1988). L-Tryptophan transaminase of a bacterium isolated from the rhizosphere of Festuca octoflora (Gramineae). Soil Biology and Biochemistry 20, 299-304.

FujIOKA, M., MoRINO, Y. \& WADA, H. (1970). Metabolism of phenylalanine. Methods in Enzymology 17a, 585-596.

haAs, D., Keel, C., Laville, J., Maurhofer, M., Oberhänsli, Th., SCHNIDER, U., VoISARD, C. \& DÉFAGo, G. (1991). Secondary metabolites of Pseudomonas fluorescens strain CHA0 involved in the suppression of root diseases. In Advances in Molecular Genetics of Plant-Microbe Interactions, vol. I, pp. 450-456. Edited by I. H. Hennecke \& D. P. S. Verma. Dordrecht, Boston \& London: Kluwer Academic Publishers.

HARTMANN, A., SINGH, M. \& KLINGMÜLlER, W. (1983). Isolation and characterization of Azospirillum mutants excreting high amounts of indoleacetic acid. Canadian Journal of Microbiology 29, 916-923.

IsHIMURA, Y. (1970). L-Tryptophan 2,3-dioxygenase (tryptophan pyrrolase) (Pseudomonas fluorescens). Methods in Enzymology 17a, 429-438.

KAPER, J. M. \& VELDSTRA, H. (1958). On the metabolism of tryptophan by Agrobacterium tumefaciens. Biochimica et Biophysica Acta 30, 401-420.

Keel, C., Voisard, C., Berling, C. H., Kahr, G. \& Défago, G. (1989). Iron sufficiency, a prerequisite for the suppression of tobacco black root rot by Pseudomonas fluorescens strain CHA0 under gnotobiotic conditions. Phytopathology 79, 584-589.

Keel, C., Wirthner, Ph., Oberhänsli, Th., Voisard, C., Burger, U., HaAs, D. \& DÉFago, G. (1990). Pseudomonads as antagonists of plant pathogens in the rhizosphere: role of the antibiotic 2,4-diacetylphloroglucinol in the suppression of black root rot of tobacco. Symbiosis 9, 327-341.

Keel, C., Maurhofer, M., Oberhänsli, Th., Voisard, C., HaAs, D. \& DÉfaGo, G. (1991). Role of 2,4-diacetylphloroglucinol in the suppression of take-all of wheat by a strain of Pseudomonas fluorescens. In Developments in Agricultural and Managed-Forest Ecology 23, Biotic Interactions and Soil-Borne Diseases, pp. 335-338 Edited by A. B. R. Beemster, G. J. Bollen, M. Gerlach, M. A Ruissen, B. Schippers \& A. Tempel. Amsterdam: Elsevier

KING, E. O., WARD, M. K. \& RANEY, D. E. (1954). Two simple media for the demonstration of pyocyanin and fluorescein. Journal of Laboratory and Clinical Medicine 44, 301-307.

KUo, T.-T. \& KosUGE, T. (1970). Role of aminotransferase and indole3-pyruvic acid in the synthesis of indole-3-acetic acid in Pseudomonas savastanoi. Journal of General and Applied Microbiology 16, 191-204.

LOPER, J. E. \& SCHROTH, M. N. (1986). Influence of bacterial sources of indole-3-acetic acid on root elongation of sugar beet. Phytopathology 76, 386-389.

Müller, M., Deigele, C. \& Ziegler, H. (1989). Hormonal interactions in the rhizosphere of maize (Zea mays L.) and their effects on plant development. Zeitschrift für Pflanzenernährung und Bodenkunde 152, 247-254

Narumiya, S., TakaI, K., Tokuyama, T., Noda, Y., Ushiro, H. \& HAYAISHI, O. (1979). A new metabolic pathway of tryptophan initiated by tryptophan side chain oxidase. Journal of Biological Chemistry 254, 7007-7015.

ORNSTON, L. N. \& STANIER, R. Y. (1966). The conversion of catechol and protocatechuate to $\beta$-ketoadipate by Pseudomonas putida. Journal of Biological Chemistry 241, 3776-3786. 
Sandberg, G., Crozier, A. \& Ernstsen, A. (1987). Indole-3-acetic acid and related compounds. In The Principles and Practice of Plant Hormone Analysis, vol. 2, pp. 169-301. Edited by L. Rivier \& A. Crozier. London: Academic Press.

SmiLEY, R. W. \& CoOK, R. J. (1973). Relationship between take-all of wheat and rhizosphere-pH in soils fertilized with ammonium vs. nitrate-nitrogen. Phytopathology 63, 882-890.

Stanisich, V. \& Holloway, B. W. (1972). A mutant sex factor of Pseudomonas aeruginosa. Genetical Research 19, 91-108.

Stutz, E. W., DÉfago, G. \& KeRN, H. (1986). Naturally occurring fluorescent pseudomonads involved in suppression of black root rot of tobacco. Phytopathology 76, 181-185.

Surico, G., IACobellis, N. S. \& Sisto, N. S. (1985). Studies on the role of indole-3-acetic acid and cytokinins in the formation of knots on olive and oleander plants by Pseudomonas syringae pv. savastanoi. Physiological Plant Pathology 26, 309-320.
Takai, K. \& Hayaishi, O. (1987). Purification and properties of tryptophan side chain oxidase types I and II from Pseudomonas. Methods in Enzymology 142, 195-216.

Tien, T. M., Gaskins, M. H. \& Hubbell, D. H. (1979). Plant growth substances produced by Azospirillum brasilense and their effect on the growth of pearl millet (Pennisetum americanum L.). Applied and Environmental Microbiology 167, 371-378.

Voisard, C., Keel, C., HaAs, D. \& Défago, G. (1989). Cyanide production by Pseudomonas fluorescens helps suppress black root rot of tobacco under gnotobiotic conditions. EMBO Journal 8, 351-358.

WelleR, D. M. \& CoOK, R. J. (1983). Suppression of take-all of wheat by seed treatments with fluorescent pseudomonads. Phytopathology 73, 463-469. 